\title{
Article
}

\section{Middle Holocene Coastal Environmental and Climate Change on the Southern Coast of Korea}

\author{
Hoil Lee, Jin-Young Lee *(D) and Seungwon Shin (D) \\ Geology Department, Korea Institute of Geoscience and Mineral Resources (KIGAM), Daejeon 34132, Korea; \\ hoillee@kigam.re.kr (H.L.); ssw7304@kigam.re.kr (S.S.) \\ * Correspondence: jylee@kigam.re.kr
}

check for

updates

Citation: Lee, H.; Lee, J.-Y.; Shin, S. Middle Holocene Coastal Environmental and Climate Change on the Southern Coast of Korea. Appl. Sci. 2021, 11, 230.

https://doi.org/10.3390/app11010230

Received: 9 December 2020

Accepted: 25 December 2020

Published: 29 December 2020

Publisher's Note: MDPI stays neutral with regard to jurisdictional claims in published maps and institutional affiliations.

Copyright: () 2020 by the authors. Licensee MDPI, Basel, Switzerland. This article is an open access article distributed under the terms and conditions of the Creative Commons Attribution (CC BY) license (https: / / creativecommons.org/ licenses/by/4.0/).
Abstract: We obtained a $15 \mathrm{~m}$ drill core from Deukryang Bay on the southwest coast of Korea, which is now an area of reclaimed land used for agriculture. We investigated changes in the depositional environment and hydrological climate responses to sea level changes using sedimentary facies, radiocarbon ages, grain-size analysis, total organic carbon (TOC), total sulfur (TS), and stable carbon isotopes $\left(\delta^{13} \mathrm{C}\right)$. Sediment deposition began at $12,000 \mathrm{cal}$ yr BP and was divided into four stages based on changes from fluvial to intertidal environments related to Holocene marine transgression events. Stage 1 (>10,000 cal yr BP) is represented by fluvial sediments; Stage $2(10,000-7080$ cal yr BP) is represented by the deposition of mud facies in an intertidal zone in response to sea level rise; Stage 3 (7080-3300 cal yr BP) was a period of gradually descending sea level following the Holocene maximum sea level and is characterized by gradual changes in TOC, TS, and C/S ratios compared with the mud facies of Stage 2. Stage 4 (3300 to present) was deposited in a supratidal zone and contains low TS and an abundance of TOC. Based on our TS and C/S ratio results, the south coast of Korea was mainly affected by sea level rise between 7000 and 3000 cal yr BP, during the middle Holocene. At $3000 \mathrm{cal}$ yr BP, sea level began to stabilize or gradually decrease. In addition, changes in $\delta^{13} \mathrm{C}$ values are clearly observed since ca. $5000 \mathrm{cal}$ yr BP, in particular, large hydrological changes via freshwater input are confirmed in 4000-3000 cal yr BP. We consider these shifts in freshwater input indicators of an increased influence of El Niño and La Niña conditions, related to the weakening of the East Asian Summer Monsoon (EASM) and changes in sea surface temperature (SST) of the Western Pacific Ocean during the middle Holocene climatic optimum (between 7800 and 5000 cal yr BP). The cooling periods of SST in East Asia between 8400 and $6600 \mathrm{cal}$ yr BP reported from the west coast of Korea are related closely to changes in vegetation (as evidenced by $\delta^{13} \mathrm{C}$ ) from 7700 cal yrs $\mathrm{BP}$ to the present in the southwest coast of Korea. We interpret the freshwater input events at 4000-3000 cal yr BP to be related to changes in SST in response to the weakening of the EASM on the southwest coast of Korea. However, additional research is needed to study the southward migration effect of the westerly jet related to SST and atmospheric circulation controlling terrestrial climate in the middle Holocene.

Keywords: organic $\delta^{13} C$; total sulfur; freshwater discharge; climate change; coastal change

\section{Introduction}

After the last glacial maximum (LGM), sea level rose rapidly; coastal plains were affected by the transgression and are distributed worldwide. On the western and southern coasts of the Korean Peninsula, the high tide-affected areas of intertidal zones were particularly affected by this sea level rise. Most of this intertidal zone is now used as arable land through reclamation.

The timing and altitude of sea level change around coastal Korea has been reported previously, with a focus on sea level high stands and their fluctuation after the maximum Holocene high stand [1-8]. These studies have documented sea level rise and climate change from geochemical analyses of coastal sediments. 
Recently, several studies have focused on the southern coast of Korea with respect to changes in sea level and climate [4,9-11]. These authors traced the mechanisms responsible for summer monsoon intensity and sea level changes using stable carbon isotopes $\left(\delta^{13} \mathrm{C}\right)$ and $\mathrm{C} / \mathrm{S}$ ratios formed by different processes in the coastal area. They also studied environmental and climatic changes based on paleo-vegetation data from pollen records. These studies were conducted on coastal sediments in the Beolgyo [4] and Goheung areas $[9,11]$, which are near the study area (Figure 1 ).

The sediments deposited during the Holocene transgression after the LGM are distributed on the coastal plains of Korea. However, it is very difficult to observe undisturbed sedimentary layers that were deposited after the sea level high stand, owing to human activities such as reclamation for farming and infrastructure development. Therefore, this study attempts to resolve this issue by comparing the results of the Beolgyo and Goheung areas to our new results from Deukryang.

Several previous studies [4,9-11], have used geochemical analysis to analyze the sedimentary environment. In particular, the total sulfur content (TS; wt.\%), total organic carbon content (TOC; wt.\%), and the ratio between total sulfur and carbon (C/S ratio) are very useful for distinguishing between terrestrial and marine environments, because the C/S ratio is related to the amount of pyrite formed in the two different sedimentary environments and can therefore be used as an indicator of salinity. Diagenetic pyrite forms more readily in marine sediments than in freshwater sediments, owing to the high concentrations of dissolved sulfate in seawater [1]. In general, where marine and freshwater environments are separated, marine sediments have low C/S ratios (0.5-5), whereas freshwater sediments have high ratios $(\geq 10)$ [12]. Brackish water that is more affected by saline water has C/S ratios of $4-11$, whereas brackish water more affected by freshwater has ratios between 11 and 17 [4,13]. The TS can also be used to classify terrestrial and marine sediments, as marine sediments typically fall between $0.3 \%$ and $3 \%[9,11,14,15]$. The $\delta^{13} \mathrm{C}_{\text {TOC }}$ value is also useful for distinguishing between marine and terrestrial organic matter origin. Terrestrial sediments are generally between $-32.5 \%$ and $-24.9 \%$, whereas values between $-21.7 \%$ and $-17.3 \%$ are typical in marine sediments [16].

Since the beginning of the Holocene, the sea level of the Korean Peninsula has risen more than 20-30 $\mathrm{m}$ above sea level $[1,6,7,17,18]$, resulting in a prominent shift from terrestrial to marine environments on the current coastal area. The transgression in the coastal area supplied sulfate and formed anoxic sedimentary environments necessary for pyrite formation. Therefore, changes in the TS have been interpreted to reflect the incursion of seawater on the peninsula, owing to sea level changes (e.g., $[6,19])$.

The variation of $\delta^{13} \mathrm{C}_{\mathrm{TOC}}$ in sediments has been widely used for tracking paleoenvironmental changes associated with sea level changes in the Korean Peninsula [9,10,20-25]. $\delta^{13} C_{\text {TOC }}$ has been applied for distinguishing between humid/dry climates, and has been used to interpret past monsoon changes and reconstruct paleoclimate, especially for the southern coast of Korea and Jeju Island. Lee et al. and Lim et al. reported abrupt changes in vegetation types around $7500 \mathrm{cal} \mathrm{yr} \mathrm{BP}$, and also found that the east Asian summer monsoon (EASM) was dominant effect on the hydrological cycle until 6000 years BP $[9,11]$. At 6000 cal yr BP, climatic change associated with SST changes in the Southwest Pacific Ocean and typhoons related to ENSO (El Niño-southern Oscillation) affected the southern coast of Korea, and gradually weakened the EASM. These results provide a globally relevant record of long-term climate change and a regional record of short-term environmental change during the Holocene transgression $[9,26-28]$.

This study aims to interpret the trends of global and regional climatic changes in response to sea level and paleoenvironmental changes during the middle Holocene based on organic geochemistry (TOC, TS, and $\delta^{13} \mathrm{C}_{\mathrm{TOC}}$ ) from a core extracted from Deukryang Bay, on the southern coast of the Korean Peninsula. 


\section{Study Area and Methods}

The study area is located on the southern coast of Korea, which has been used for agriculture for the last 100 years. In particular, sediments are sourced from the surrounding mountains and accumulate in the basin, except for the southern part, where sediments precipitate in the marine environment. Deukryang Bay is an inner bay where seawater flows from south to north, and which shallows from the southeast to the northwest. A seawall has been built in the southern part of the bay, and freshwater flows into the bay from small streams, including the Deuknyang and Joseong streams. According to Korean Meteorological Administration, the annual precipitation is $1500-2000 \mathrm{~mm}$, and summer precipitation accounts for $70 \%$ of the total annual precipitation.

Using a general map of the area produced in the Japanese colonial era during the 1910s, we verified the locations of intertidal zones and coastal sands on the coastline before reclamation activity. Therefore, the sediment cores obtained include records of the depositional environment below the present sea level. Core BSL11 was obtained near the channel in the intertidal zone; the current tidal range is $\sim 3.5 \mathrm{~m}$ (Figure 1).
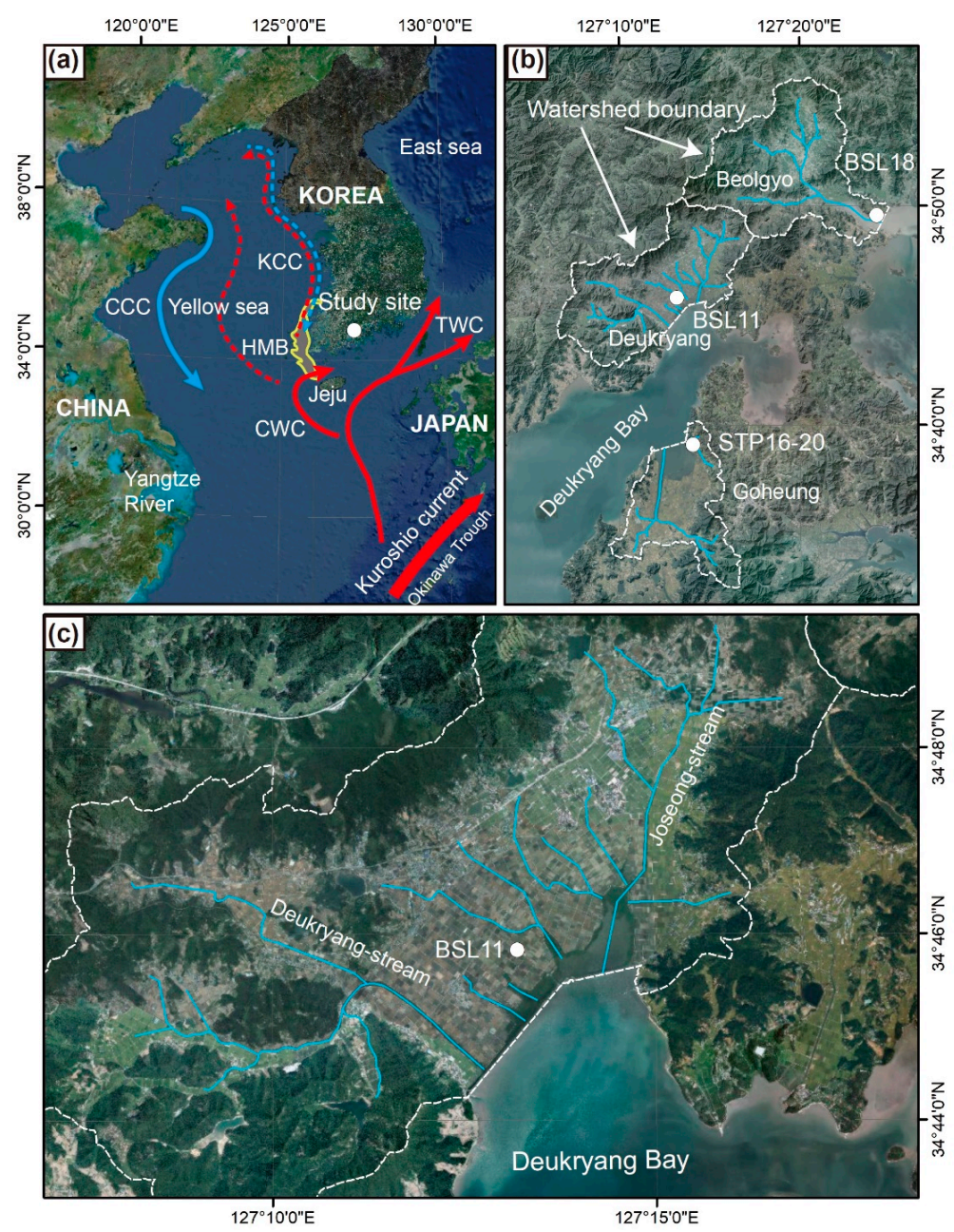

Figure 1. (a) Location of the BSL11 core site and surface currents in the Yellow Sea and East China Sea. Blue (red) arrows represent cold (warm) currents. Dashed arrows indicate seasonally varying currents. TWC, Tsushima Warm Current; CWC, Cheju Warm Current; YSWC, Yellow Sea Warm Current; KCC, Korean Coastal Current; CCC, Chinese Coastal Current; CDW, Changjiang Diluted Water. The Heuksan Mud Belt (HMB) is marked by gray shading (modified from Bae et al. [29]). (b) Aerial photo around Deukryang, Beolgyo, and Goheung watersheds. (c) Aerial photo of Deukryang watershed which has more outlets than Beolgyo, and Goheung watersheds. For interpretation of the references to color in this figure legend, the reader is referred to the Web version of this article. 
Core BSL11 comprises $15 \mathrm{~m}$ of sediments; samples for grain-size and geochemical analyses were collected every $10 \mathrm{~cm}$, while radiocarbon dating samples were collected at specific depth where plant or shell fragments appear (Table 1). Radiocarbon dating of samples was conducted using an accelerator mass spectrometer (AMS) at the Korean Institute of Geoscience and Mineral Resources (KIGAM), Daejeon, Korea. For grain-size analysis, the samples were treated with $35 \% \mathrm{H}_{2} \mathrm{O}_{2}$ to decompose organic matter and then boiled in $1 \mathrm{~N} \mathrm{HCl}$ for $2 \mathrm{~h}$ to remove carbonates and iron oxides. Samples were then rinsed three times using distilled water, then treated with an ultrasonic vibrator for $30 \mathrm{~s}$ to keep them in suspension and facilitate dispersion. We then performed grain-size analysis using a Mastersizer 2000 laser analyzer (Malvern Instruments, Worcestershire, UK).

Table 1. Results of AMS ${ }^{14} \mathrm{C}$ dating and calibrated dates for core BSL11.

\begin{tabular}{cccccc}
\hline Depth $(\mathbf{m})$ & ${ }^{\mathbf{1 4}} \mathbf{C} \mathbf{B P}( \pm \mathbf{1} \mathbf{\sigma})$ & cal BP $( \pm \mathbf{2} \mathbf{\sigma})^{\mathbf{a}}$ & $\boldsymbol{\delta}^{\mathbf{1 3}} \mathbf{C}$ & Lab. Code & Dated Material \\
\hline 1.16 & $3460 \pm 40$ & $3740 \pm 100$ & -25.1 & ITg120304 & Bulk soil \\
2.41 & $3610 \pm 40$ & $3960 \pm 130$ & -24.5 & ITg120298 & Plants \\
2.46 & $3680 \pm 40$ & $4030 \pm 120$ & -31.5 & ITg120326 & Plants \\
2.59 & $3520 \pm 30$ & $3790 \pm 90$ & -30.2 & ITg120327 & Plants \\
3.45 & $4510 \pm 30$ & $5180 \pm 130$ & 1.7 & ITg130034 & Shells \\
4.38 & $5400 \pm 30$ & $6170 \pm 120$ & 3.2 & ITg130035 & Shells \\
5.3 & $5570 \pm 30$ & $6360 \pm 50$ & 0.6 & ITg130036 & Shells \\
6.65 & $6590 \pm 30$ & $7470 \pm 100$ & 0.2 & ITg130037 & Shells \\
7.05 & $4420 \pm 30$ & $5080 \pm 200$ & 2.4 & ITg130038 & Shells \\
9.29 & $7290 \pm 50$ & $8100 \pm 100$ & 1.4 & ITg140029 & Shells \\
12.19 & $4680 \pm 40$ & $5450 \pm 130$ & -32.5 & ITg120328 & Plants \\
12.22 & $5450 \pm 40$ & $6250 \pm 70$ & -20.9 & ITg130250 & Shells \\
13.47 & $9050 \pm 40$ & $10220 \pm 40$ & -25.5 & ITg120296 & Plants soil \\
13.52 & $10210 \pm 50$ & $11910 \pm 190$ &
\end{tabular}

${ }^{a}$ Calibrated with Radiocarbon Calibration Program (CalPal) (http://c14.arch.ox.ac.uk).

For TOC and TS analyses, samples were treated with $1 \mathrm{~N} \mathrm{HCl}$ for $1 \mathrm{~h}$ to remove carbonates and iron oxides then rinsed three times using distilled water. Approximately 3-5 mg of the treated sample was then loaded into a tin combustion cup. The TOC and TS were determined using a CNS elemental analyzer (vario Micro cube; Elementar, Langenselbold, Germany). The C/S ratio was calculated using TOC and TS. Stable carbon isotope $\left(\delta^{13} \mathrm{C}_{\mathrm{TOC}}\right)$ analyses of $\mathrm{HCl}$-treated samples were analyzed using an isotope ratio mass spectrometer (Isoprime100; G.V. Instruments, Manchester, UK) connected to a CNS elemental analyzer. Results are expressed in delta $(\delta)$ notation of the Vienna Pee Dee belemnite standard (VPDB). The standard CH6 (sucrose, $\delta^{13} \mathrm{C}=-10.45 \pm 0.033 \%$ ) was obtained from the International Atomic Energy Agency (IAEA) and has a precision of $0.2 \%$ or more for replicate measurements.

\section{Results}

\subsection{Lithology}

Core BSL11 was divided into units 1 and 2 (Figure 2). Unit 1 (13-14.9 m depth; -0.9 to $-12.7 \mathrm{~m}$ a.s.l.) consists mainly of gravel and sand, which overlie basement rock. Grains in the gravels are mainly pebble-sized to $3 \mathrm{~cm}$ in diameter and sub-angular. Yellowish brown fine-grained sand occurs between 13.5 and $13.8 \mathrm{~m}$, bluish gray clay with shell fragments between 13 and $13.5 \mathrm{~m}$. 


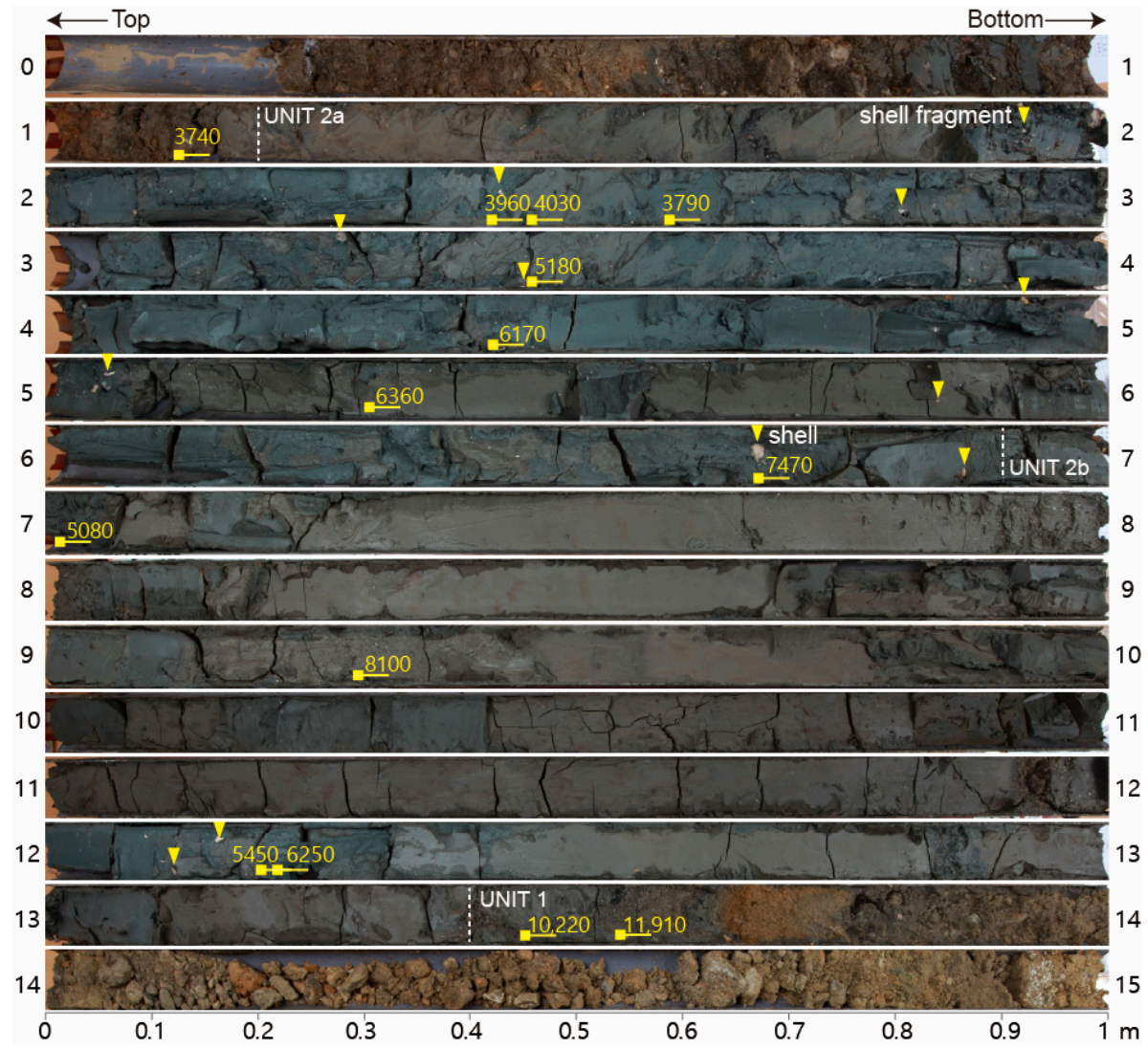

Figure 2. Photographs of core BSL11 recovered from the Deukryang area on the southwest coast of Korea. Yellow squares and numbers indicate the location of samples and ages of plant fragments at each depth. Yellow inverted triangles indicate shell locations. Dashed lines indicate boundaries between each sedimentary unit.

Unit 2 (1.2-13 $\mathrm{m}$ depth; -0.9 to $-12.7 \mathrm{~m}$ a.s.1.) is composed mainly of clay intercalated with occasional sandy clay and fine-grained sand layers. A yellowish brown zone from 1.2 to $1.5 \mathrm{~m}$, indicating oxidation, is observed in the upper part of Unit 2. Unit 2 is divided two sub units; Unit $2 \mathrm{a}(1.2-7 \mathrm{~m})$ is distinguished from Unit $2 \mathrm{~b}(7-13 \mathrm{~m})$ by a high number of shell fragments. The uppermost part of the core $(0-1.2 \mathrm{~m})$ is interpreted as a disturbance layer caused by reclamation and agricultural cultivation.

\subsection{Age Model}

Radiocarbon ages are plotted as a depth-age curve (Figure 3). The age model was generated based on 3960 years at a depth of $2.41 \mathrm{~m}$ except for a disturbance layer at a depth of $0-1.2$. Several ages at depths of $12.19,12.22$, and $7.05 \mathrm{~m}$, which were clearly disturbed during the drilling process, were excluded from our final results. Results from shells, based on comparison with plants and shells from the same depth interval in the Yeongsan Estuary in southwestern Korea, were influenced by the marine reservoir effect and were biased by 470 years $[4,8]$. After applying these corrections, the radiocarbon ages from core BSL11 yielded ages of ca. $3400 \mathrm{cal} \mathrm{yr} \mathrm{BP}$ at a depth of $1.2 \mathrm{~m}$ and ca. 12,000 cal yr BP at a depth of $13.52 \mathrm{~m}$, indicating the entire core was deposited during the Holocene. In this study, we focused on the middle Holocene, from ca. 8000 to 3000 cal yr BP. 


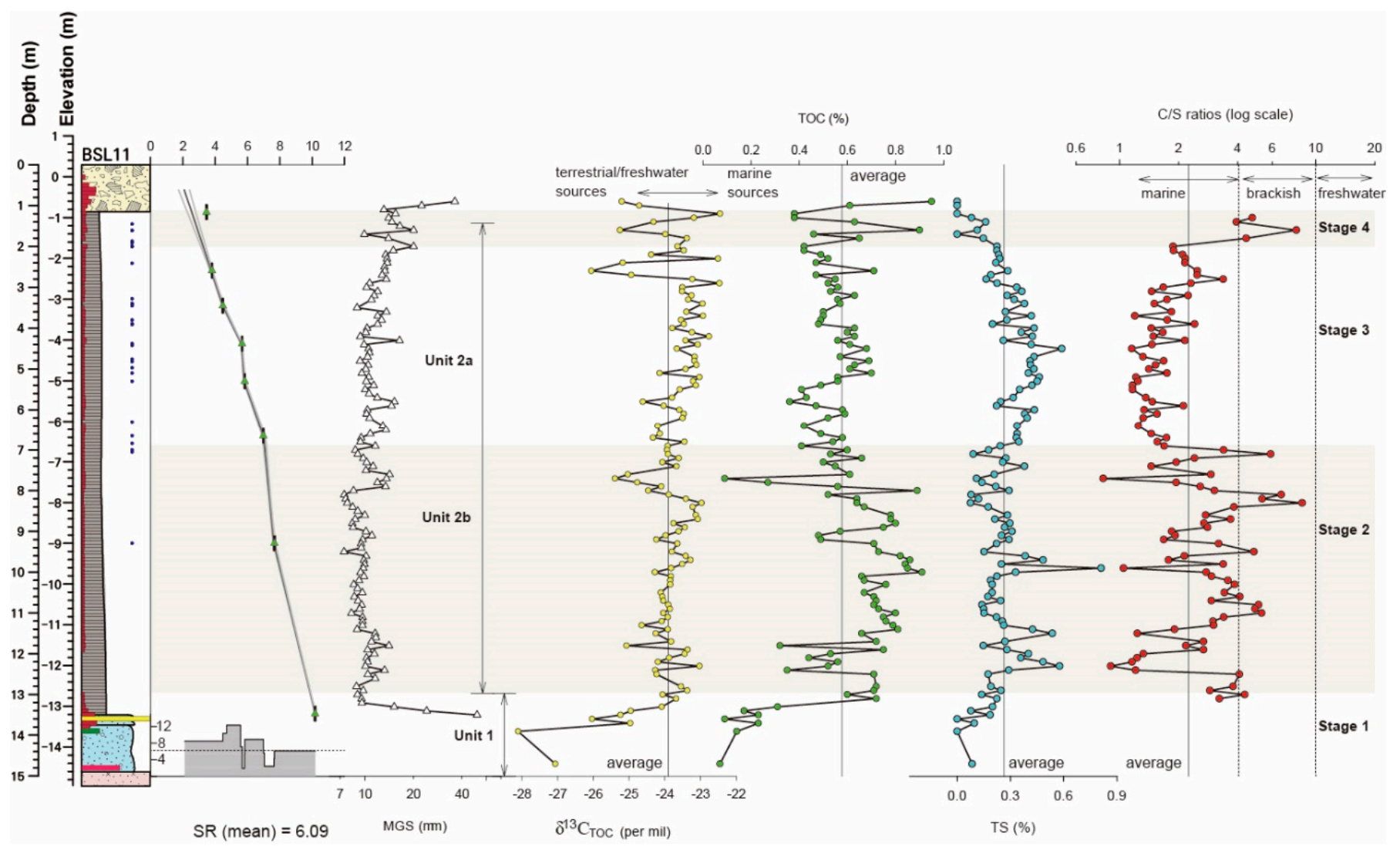

Figure 3. Stratigraphic section, age-depth curve, sedimentation rates, and sedimentary proxies for core BSL11 (MGS: median grain size, TOC: total organic carbon, TS: total sulfur, C/S: carbon/sulfur, and SR: sedimentation rate). Horizontal bars and blue dots in the stratigraphic section indicate grain size and shell locations.

\subsection{TOC, TS, CS Ratio, and Radiocarbon Isotopes $\left(\delta^{13} C_{T O C}\right)$}

The $\delta^{13} C_{\text {TOC }}$ values from core BSL11 ranged from $-22.5 \%$ to $-28.1 \%$, with an average of $-23.9 \%$. The lowest $\delta^{13} \mathrm{C}_{\text {TOC }}$ values were observed at 2.6 and $7.65 \mathrm{~m}$ and were $-26.0 \%$ and $-25.6 \%$, respectively. The maximum values for TOC and TS were $0.95 \%$ and $0.8 \%$, and the average values were $0.58 \%$ and $0.26 \%$, respectively.

\section{Discussion}

\subsection{Depositional Environments}

The results of age dating, lithology, and geochemical analyses from core BSL11 indicate paleoenvironmental changes in the study area. Based on our TS and C/S ratio data, we divided the core into four stages during the Holocene (Figure 3).

\subsubsection{Stage 1 (Prior to ca. $10,000 \mathrm{cal} \mathrm{yr} \mathrm{BP)}$}

Stage 1 (elevation -12.52 to $-14.52 \mathrm{~m}$ ) was deposited at ca. 10,000 cal yr BP, and comprises gravelly sand overlain by a layer of fining-upward clay (Figure 3). During this stage, clay contents and $\delta^{13} \mathrm{C}_{\mathrm{TOC}}$ values increase simultaneously, TS was close to $0 \%$, and the C/S ratio is not shown owing to low TS. The $\delta^{13} \mathrm{C}_{\mathrm{TOC}}$ values of Stage 1 could be interpreted as an increase in organic matter from marine sources (relative to terrestrial sources). The TS value in the lowermost portion of this interval is $<0.3 \%$, indicating a terrestrial origin for these sediments (Figure 3). Considering the well-documented global sea level transgression during the Holocene, we surmise the gravelly sand in the lower part, which includes both angular and well-rounded gravel, was not affected by the marine transgression. The decreasing grain size toward the upper part of the interval is interpreted 
to indicate an environment in which the water level of the terrestrial stream increased gradually in response to sea level rise.

\subsubsection{Stage 2 (ca $10,000 \mathrm{cal}$ yr BP to ca $7080 \mathrm{cal}$ yr BP)}

Stage 2 corresponds to Unit $2 \mathrm{~b}$ (elevation -6.42 to $-12.52 \mathrm{~m}$ ) where shells are rare (Figure 3). The lower part of stage 2 has a larger grain size than the upper part. Stage 2 formed at 10,000-7080 cal yr BP and experienced a rapid rise in global sea level following the LGM. Bird et al. proposed an abrupt increase in sea level, from $-17 \mathrm{~m}$ in $9500 \mathrm{cal} \mathrm{yr}$ BP to $-3 \mathrm{~m}$ in $8000 \mathrm{cal} \mathrm{yr} \mathrm{BP}$, in the Sunda shelf in Southeast Asia [1]. Tanigawa et al.reported that the relative sea level of Toyooka Basin rose from $-31.05 \mathrm{~m}$ in 10,000 cal yr BP to $-4 \mathrm{~m}$ in $7900 \mathrm{cal}$ yr BP and to $-0.47 \mathrm{~m}$ in $6700 \mathrm{cal} \mathrm{yr} \mathrm{BP}$ [6]. Recently, Xiong et al. suggested that sea level rose from $-8.58 \mathrm{~m}$ at $8260 \mathrm{cal} \mathrm{yr} \mathrm{BP}$ to $+0.17 \mathrm{~m}$ at $7430 \mathrm{cal} \mathrm{yr} \mathrm{BP}$ at a site in the Yellow Sea in China [7] (Figure 4). Therefore, Stage 2 in our study area was likely affected by marine transgression.

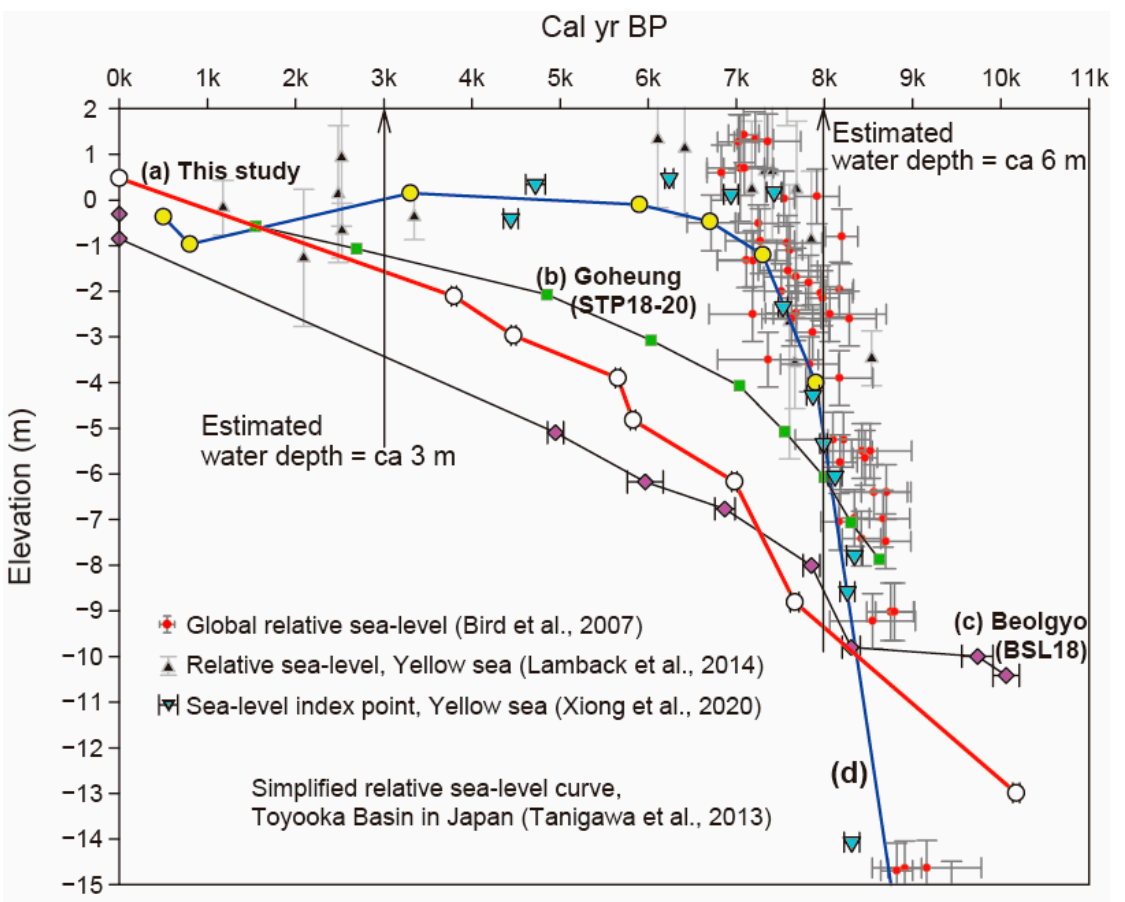

Figure 4. Comparison of estimated sea level curves from (a) the Deukryang area (core BSL11, this study; white circles on red line), (b) the Goheung area (core STP18-20 [11]; green squares on blackline), (c) the Beolgyo area (core BSL18 [4] purple diamonds on black line), and (d) simplified relative sea level curve of the Toyooka basin [6] turquoise inverted triangles on blue line). Other points refer to sea level fluctuations in the Yellow sea between China and around the coastal area of Korea [3,7] and global relative sea level [1].

In our record, the most pronounced effect from the marine transgression is the change in grain size. In the clay layer from -12.52 to $-10.82 \mathrm{~m}$ in elevation, which is part of Unit $2 \mathrm{~b}$, TOC values range from $0.3 \%$ to $0.8 \%$, and TS values exhibit two peaks from $0.14 \%$ to $0.53 \%$. These changes may be related to sea level rise, but they are not consistent with known temporal changes in global sea level. In addition, the clay layer, which was likely deposited in the intertidal zone, has a relatively high age uncertainty due to the low number of radiocarbon dating analyses. Therefore, it is very difficult to estimate the age of the marine transgression from a specific elevation in the core. In addition, the sedimentation rate during sea level rise in this area was relatively low at $0.6 \mathrm{~mm} /$ year, compared with the high value of $0.8 \mathrm{~mm} /$ year observed at the same time in other studies [4]. However, the highest TS value occurs at an elevation of $-9.42 \mathrm{~m}$, which is near the sample that was age dated from this interval. This TS peak ( $0.8 \%)$ occurs at ca. $8000 \mathrm{cal} \mathrm{yr} \mathrm{BP,} \mathrm{which} \mathrm{may} \mathrm{be}$ 
due to the marine transgression, since most studies indicate a sea level rise of $6 \mathrm{~m}$. TOC is also the highest during this interval $(0.8-0.9 \%)$, and the $\mathrm{C} / \mathrm{S}$ ratio is very low (1.0). It is difficult to provide the exact timing of the transgression in this area, but it is clear that by ca. $8000 \mathrm{cal} \mathrm{yr} \mathrm{BP}$ the area had been affected by the Holocene transgression. Therefore, the sedimentary environment had changed from a fluvial to an intertidal zone in response to sea level rise at ca. $8000 \mathrm{cal}$ yr BP.

A distinct peak where the grain size increases and TOC decreases markedly is observed at an elevation of $-7.22 \mathrm{~m}$ at ca. $7280 \mathrm{cal} \mathrm{yr}$ BP, which records a dramatic decrease in $\delta^{13} \mathrm{C}_{\mathrm{TOC}}$ values to $-25.3 \%$ (Figure 5). This value indicates that the organic matter formed in a terrestrial environment, whereas the TOC, TS, and C/S ratios indicate a marine depositional environment. Therefore, we interpret this interval as an event in which sediments from terrestrial environments were temporarily supplied to the marine environment.

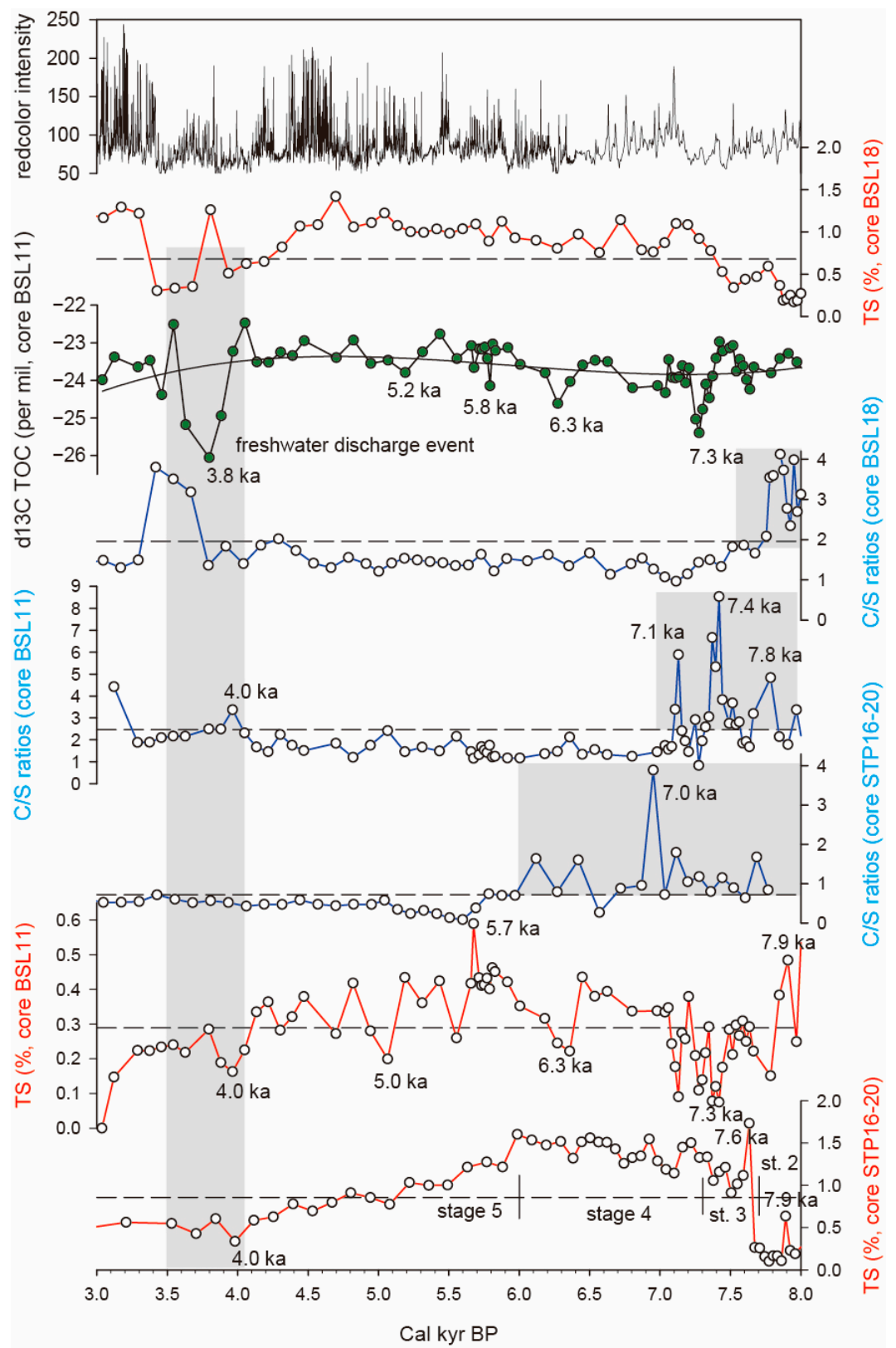

Figure 5. Comparison of sedimentary environmental proxies $\left(\delta^{13} \mathrm{C}_{\mathrm{TOC}}, \mathrm{TS}, \mathrm{C} / \mathrm{S}\right.$ ratios, and red color intensity) from the Deukryang area with reconstructed climate change on the southwestern coast of Korea (Goheung area from core STP18-20 [11], and Beolgyo area from core BSL18 [4]). 


\subsubsection{Stage 3 (7080 to ca. 3300 cal yr BP)}

Stage 3 was deposited during 7080-3300 cal yr BP and has an elevation of $-6.42 \mathrm{~m}$ to $-1.52 \mathrm{~m}$. This period corresponds to a stagnant or gradually descending sea level following the sea level maximum in the middle Holocene, during which water depths were $>6 \mathrm{~m}$ greater than present levels at $8000 \mathrm{cal} \mathrm{yr} \mathrm{BP}$ and $1 \mathrm{~m}$ greater at $3000 \mathrm{cal} \mathrm{yr} \mathrm{BP.} \mathrm{There} \mathrm{is}$ almost no change during this interval in the grain size of intertidal mud, and the changes in TOC, TS, and the C/S ratio are relatively small compared with the changes observed during Stage 2. Stage 3 corresponds to Unit $2 \mathrm{a}$ and is represented by abundant shell fragments, which suggests that the sedimentary environment was different from that during Stage 2 (Figure 3). We therefore interpret the sedimentary environment during Stage 3 to be an intertidal zone in which biological activity increased gradually as the water depth decreased via a lowering of sea level or by increased sediment supply. In particular, the fine-grained sand layers observed during the transition to the intertidal zone temporarily changed, owing to the supply of coarser sediments, which might have occurred during typhoons or coastal storms.

The C/S ratios in Stage 3 indicate a marine depositional environment, but this differs from the sudden change in C/S ratios related to sea level rise in Stage 2. The highest TS value in this interval occurred at $5680 \mathrm{cal} \mathrm{yr} \mathrm{BP,} \mathrm{whereas} \mathrm{the} \mathrm{lowest} \mathrm{occurred} \mathrm{at} 3960 \mathrm{cal} \mathrm{yr} \mathrm{BP.}$ The TOC value was lowest at $6270 \mathrm{cal}$ yr BP and highest at $3800 \mathrm{cal} \mathrm{yr} \mathrm{BP}$. The $\delta^{13} \mathrm{C}_{\mathrm{TOC}}$ value was lowest at $3800 \mathrm{cal}$ yr BP, when TOC was the highest (Figure 3). This indicates a large fresh water input during Stage 2, which supplied a large amount of organic matter.

\subsubsection{Stage 4 (ca. 3300 cal yr BP to Present)}

Stage 4 is interpreted as an upper intertidal zone, with very low TS and variable TOC values (Figure 3). Increases in grain size, TOC, and C/S ratios and a decrease in TS indicate this interval was influenced by terrestrial freshwater environments. The large fluctuation in $\delta^{13} \mathrm{C}_{\mathrm{TOC}}$ values indicates an unstable environment that is influenced by marine and freshwater inputs and is interpreted as an upper intertidal zone temporarily affected by freshwater.

\subsection{Middle Holocene Paleoclimate and $\delta^{13} \mathrm{C}$ Variability}

Changes in the strength of the EASM have been considered an important factor in climate change on the Korean Peninsula. From 8000 to $3000 \mathrm{cal} \mathrm{yr} \mathrm{BP,} \mathrm{the} \mathrm{results} \mathrm{from}$ core BSL18 of the Beolgyo area and core STP16-20 from the Goheung area show C/S ratios from 0 to 4 , whereas core BSL11 from the Deukryang area has C/S ratios of 0-9 (Figure 5). As shown in Figure 5, the average of the $\mathrm{C} / \mathrm{S}$ values in the Goheung and Beolgyo areas is $<2$, whereas the Deukryang area $\mathrm{C} / \mathrm{S}$ average values are $>2$. The $\mathrm{C} / \mathrm{S}$ ratios in these three areas indicate a marine environment after $7000 \mathrm{cal}$ yr BP. Compared with the Goheung region, where the entire core was deposited in a marine environment except for the peak at $7000 \mathrm{cal}$ yr BP, the Bulgyo and Deukryang areas have C/S ratios of $\geq 3$ before 7000 cal yr BP, indicating a marine environment affected by freshwater until the Holocene climatic optimum. These results indicate that the Beolgyo and Deukryang areas were largely affected by freshwater, and in particular, the Deukryang area was more affected by freshwater than the Beolgyo area. As seen from C/S ratios, the Beolgyo area underwent early changes from a stable marine environment to an unstable environment of freshwater and seawater input since at $7760 \mathrm{cal} \mathrm{yr} \mathrm{BP,} \mathrm{whereas} \mathrm{the} \mathrm{Goheung} \mathrm{area} \mathrm{was}$ in a relatively unstable environment until ca. $6000 \mathrm{cal}$ yr BP. The Deukryang area was continuously unstable until ca. $7000 \mathrm{cal} \mathrm{yr} \mathrm{BP}$. This period is known to be the period during which global sea level rose rapidly and then gradually stabilized. Therefore, the data indicate that the Beolgyo, Goheung, and Deukryang areas were simultaneously affected by sea level rise and associated changes in regional sedimentation.

A recent study reported that the Goheung area (STP16-20) had changed to a subtidal environment at ca. $7500 \mathrm{cal} \mathrm{yr} \mathrm{BP}$ and shifted to an environment dominated by brackish marine input after $6000 \mathrm{cal} \mathrm{yr} \mathrm{BP} \mathrm{[11].} \mathrm{This} \mathrm{means} \mathrm{that} \mathrm{the} \mathrm{local} \mathrm{environmental} \mathrm{changes} \mathrm{in}$ 
the region are not identical, despite the fact that cores BSL11 and STB16-20 were deposited on the same coast of Deukryang Bay. Conversely, providing that the same change is observed in different sedimentary environments, this means that it is at least possible to interpret more widely. Given the above information, we assume that the effect of overall sea level rise was complete by ca. 7000 cal yr BP, and the southwest Korean coast remained a relatively stable environment in regard to changes in sea water and freshwater for the remainder of the Holocene. Unlike the changes in C/S ratios, changes in TS values tend to be very similar in the Deukryang (BSL11) and Goheung (STP16-20) areas located in the Deukryang Bay, whereas the TS values in the Beolgyo (BSL18) area of Yeoja Bay varied. This suggests that TS values, which are highly dependent on local salinity changes, represent regional differences in sea level and freshwater inputs. Therefore, it is reasonable that sea level rise and the changes in the sedimentary environment that appear in the Deukryang area (core BSL11) are similar to those in the Goheung area (core STP16-20).

The unusually large variations in TS values identified in the Deukryang area (core BSL11) indicate that the study area was relatively sensitive to fluvial and marine input. Thus, the change in TS values between around 6300 and $5200 \mathrm{cal}$ yr BP is observed only in the Deukryang area, unlike the Goheung and Beolgyo areas. These changes in TS values coincide with low $\delta^{13} \mathrm{C}_{\mathrm{TOC}}$ values at 6300, 5800, and $5200 \mathrm{cal}$ yr BP (Figure 5), with decreasing TS and $\delta^{13} \mathrm{C}_{\text {TOC }}$ values at 5200 and $6300 \mathrm{cal}$ yr BP. These decreases in TS and $\delta^{13} \mathrm{C}_{\mathrm{TOC}}$ are consistent with an influx of organic matter from freshwater from terrestrial sources. However, TS values increase at ca. $5800 \mathrm{cal}$ yr BP, while the $\delta^{13} \mathrm{C}_{\mathrm{TOC}}$ values are constant or decreasing. Based on these results, we regard the changes observed at 5200 and $5300 \mathrm{cal}$ yr BP as being caused by events related to freshwater input from terrestrial environments, but that the changes observed at 5800 cal yr BP were caused by changes in the marine environment. These results were not observed for the Beolgyo or Goheung areas (cores BSL18 and STP16-20, respectively). Instead, freshwater input from the Beolgyo area occurred simultaneously in the Deukryang area since ca. 5000 cal yr BP. Lim et al. reported freshwater input events at 4300 and 3600 cal yr BP from the Beolgyo area (core BSL18) [4]. Given the error range of the age-depth model, this freshwater input event may be the same as that identified at $3600 \mathrm{cal}$ yr BP in the Deukryang area. This change is not identified in the Goheung area, and further research is therefore required to understand this event. An important similarity in the freshwater input sources of the Beolgyo and Deukryang areas is that both watersheds are located in the inland area of the Korean Peninsula. Conversely, the Goheung area has a relatively strong influence from freshwater from the very small catchments in the Goheung Peninsula. This geographic location means that climate change in the Goheung area is mainly affected by the marine environment, and similar changes in the Goheung area and Deungryang area may have been attributed to changes in the marine environment. Therefore, we interpret the freshwater input events in the Beolgyo area at ca. $4300 \mathrm{cal}$ yr BP to have been caused by hydrological climate change in the southern coast of Korea. In addition, the freshwater input at ca. $3600 \mathrm{cal} \mathrm{yr} \mathrm{BP,}$ which is recorded in both the Beolgyo and Deukryang areas, is interpreted as a more severe impact of hydrological climate change (relative to that observed at ca. $4300 \mathrm{cal} \mathrm{yr} \mathrm{BP}$; Figure 6). 


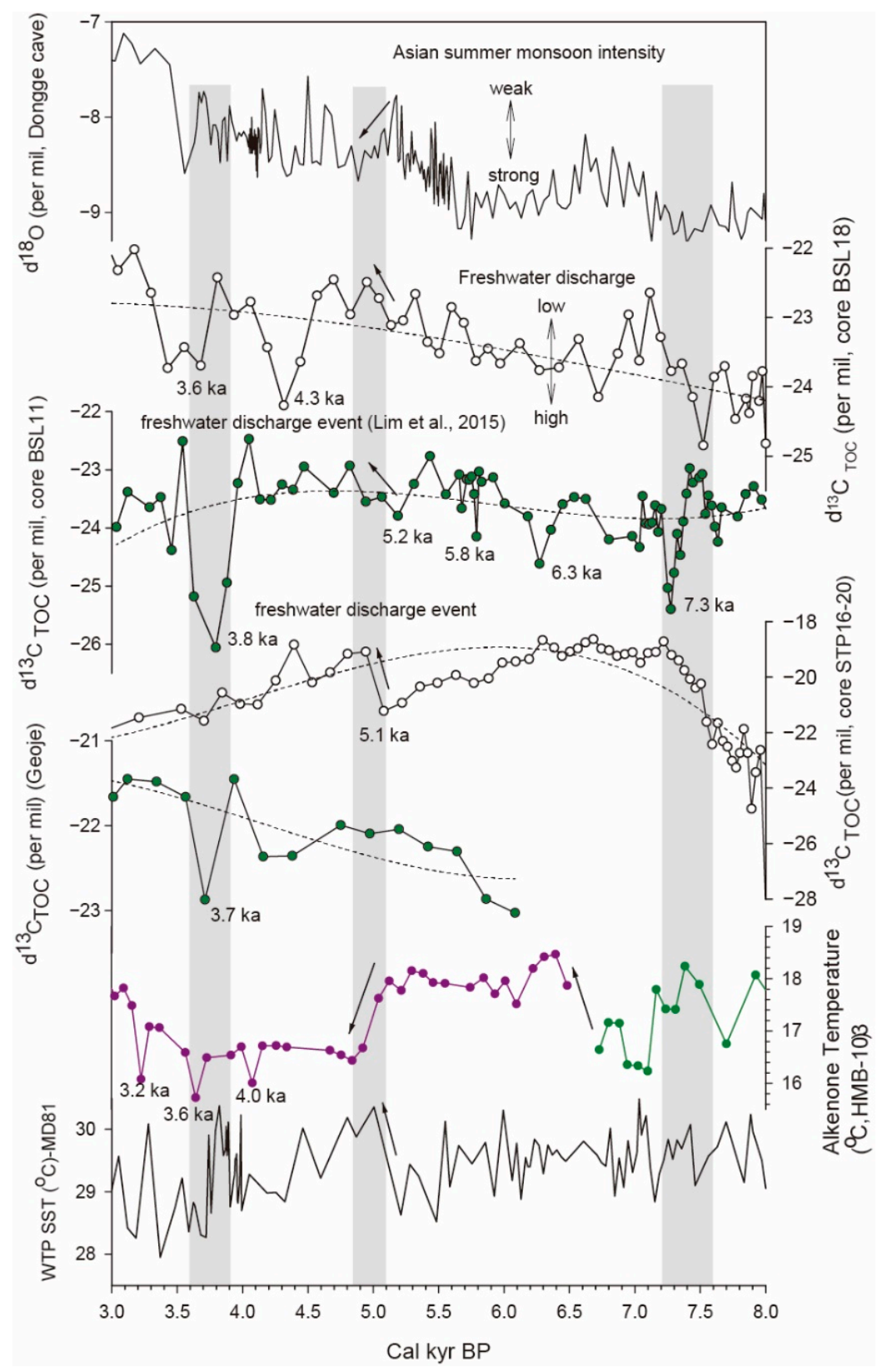

Figure 6. Comparison of $\delta^{13} C_{\text {TOC }}$ curves from the Deukryang area cores STP16-20 [11], BSL18 [4], and BSL11 (this study) with the Asian monsoon index [30], sea surface temperature data [31], and alkenone temperature [29].

\subsection{Climate Change and Driving Forces in the Beolgyo Area during the Middle Holocene}

As discussed in Section 1, changes in the $\delta^{13} C_{\mathrm{TOC}}$ values are important for freshwater input interpretation in this area. In order to interpret the factors causing changes in the sedimentary environment, the origin of sediment and changes in vegetation must be considered simultaneously. Lee et al. reported a rapid change in vegetation and environment in the Goheung area on the southern Korean coast at ca. $7500 \mathrm{cal}$ yr BP and surmised that the influence of the EASM prevailed until ca. $6000 \mathrm{cal} \mathrm{yr} \mathrm{BP,} \mathrm{before} \mathrm{the}$ influence of the EASM weakened, affecting climate change associated with SST in the southwestern Pacific and typhoons related to El Niño conditions [11]. This coincides with the period of decreasing SST in the southwestern coast of the Korean Peninsula from 6600 to $8400 \mathrm{cal}$ yr BP [29]. Therefore, changes in the vegetation environment (as evidenced by carbon isotopes) reported at the same time as sea level change on the west coast are 
interpreted to be related to the effect of atmospheric circulation due to climate change. This period can be interpreted as indicative of climate change and the southward migration of the westerly jet, which was suggested as the cause of the decrease in SST [29].

Between 5100 and 4900 cal yr BP, the intensity of EASM tended to decrease, and carbon isotopes increased in the Deukryang, Beolgyo, and Goheung areas (Figure 6). This period corresponds to a rapid decrease in summer SST in the Yellow Sea. In addition, the red color intensity trend shows that the TS peak of Deukryang area (core BSL11) corresponds to the time period from 5000-3000 cal yr BP (Figure 5). The climate change induced by the weakening EASM reported by Lee et al. coincides with decreases in the summer SST, and sea level decreased gradually with temperature after the Holocene optimum period [11]. This is also consistent with the interpretation that the influence of El Niño and La Niña conditions was caused by changes in SSTs in the South Pacific, which became stronger as the EASM weakened [4,9-11]. Since the interpretation of the westerly jet migration during this period was suggested by Bae et al. [29], further study is needed to relate the influences of El Niño and La Niña conditions with the westerly jet migration. Nevertheless, it is possible to infer that changes in land hydrology caused by the influences of El Niño and La Niña conditions resulted in increased freshwater input, because changes in land hydrological events, such as typhoons and freshwater input, have been reported in many areas between 5100 and 3000 cal yr BP. However, it is not clear how the westerly jet migration relates to both hydrological change in the southern coast and the weakening of the EASM. If the cause of the weakening of the EASM on the west coast is due to the migration of the westerly jet, it is possible to better understand the changing hydrology on the west and south coast of the Korean Peninsula in the middle Holocene. In addition, further research is needed to understand the difference in the intensity of the hydrological changes recorded by the sediments in the area, which is dependent on the pathway of the typhoon.

\section{Conclusions}

The study area in Deukryang Bay is on the southwest coast of Korea, which is now used as reclaimed land for agricultural purposes. We analyzed the sedimentary facies, radiocarbon isotope ages, grain size, TOC, TS, and $\delta^{13} \mathrm{C}$ from a $15 \mathrm{~m}$ drill core. We determined that sedimentary deposition began prior to $12,000 \mathrm{cal} \mathrm{yr} \mathrm{BP}$ and can be divided into four stages based on fluvial to intertidal depositional environments influenced by Holocene marine transgressions.

Stage 1 began before 12,000 cal yr BP and is represented by fluvial deposits exhibiting a fining-upward trend that begins with gravelly sand. Stage 2 represents the period from 10,000 to $7080 \mathrm{cal}$ yr BP and consists of intertidal mud deposits and a rapid change in TOC and TS that reflect a rapid rise in sea level. Stage 3 is the period from 7080 to 3300 cal yr BP and records a gradual decrease in sea level after the Holocene maximum. During Stage 3 there is no change in the intertidal mud deposit facies, but the TOC, TS, and C/S ratio changes are relatively small. Stage 4 is from $3300 \mathrm{cal} \mathrm{yr} \mathrm{BP}$ to the present and records a change from an intertidal zone with very low TS values to a supratidal zone with a pronounced change in TOC values.

During the period from 8000 to $3000 \mathrm{cal}$ yr BP (middle Holocene), the area was primarily affected by sea level rise until 7000 cal yr BP. Changes in vegetation (as evidenced by $\delta^{13} \mathrm{C}$ values) are apparent at ca. $5000 \mathrm{cal}$ yr BP, when sea level was either stabilized or gradually decreasing. In particular, large hydrological changes attributed to freshwater input are indicated at 7200 and $3800 \mathrm{cal}$ yr BP, with even greater changes related to freshwater input observed between 4000 and $3000 \mathrm{cal}$ yr BP.

The cooling periods of SST in East Asia from 8400 to 6600 cal yr BP reported for the western coast of Korea are closely related to changes in vegetation (from $\delta^{13} \mathrm{C}_{\mathrm{TOC}}$ values) at $7700 \mathrm{cal}$ yr BP in the southwestern coast of Korea. Freshwater input events between 4000 and $3000 \mathrm{cal}$ yr BP are interpreted to be related to changes in SST associated with the weakening of the EASM in the southwest Korean coast. Additional research is needed to 
study the southward migration effect of the westerly jet related to SST and atmospheric circulation that control terrestrial climate in the middle Holocene.

Author Contributions: J.-Y.L. designed the study and analyzed. H.L. and analyzed and drafted the manuscript. S.S. contributed to the analyses and discussion. All authors have read and agreed to the published version of the manuscript.

Funding: This research was funded by a grant (GP2020-003) and grant (GP2020-014) from Basic Research Project of the Institute of Geoscience and Mineral Resources (KIGAM) funded by the Korean Ministry of Science and ICT.

Institutional Review Board Statement: Not applicable.

Informed Consent Statement: Not applicable.

Conflicts of Interest: The authors declare no conflict of interest.

\section{References}

1. Bird, M.I.; Fifield, L.K.; Teh, T.S.; Chang, C.H.; Shirlaw, N.; Lambeck, K. An inflection in the rate of early mid-Holocene eustatic sea-level rise: A new sea-level curve from Singapore. Estuar. Coast. Shelf S 2007, 71, 523-536. [CrossRef]

2. Cho, A.; Cheong, D.; Kim, J.C.; Shin, S.; Park, Y.H.; Katsuki, K. Delta Formation in the Nakdong River, Korea, during the Holocene as inferred from the diatom assemblage. J. Coast. Res. 2017, 33, 67-77. [CrossRef]

3. Lambeck, K.; Rouby, H.; Purcell, A.; Sun, Y.; Sambridge, M. Sea level and global ice volumes from the Last Glacial Maximum to the Holocene. Proc. Natl. Acad. Sci. USA 2014, 111, 15296-15303. [CrossRef] [PubMed]

4. Lim, J.; Lee, J.-Y.; Kim, J.-C.; Hong, S.-S.; Yang, D.-Y. Holocene environmental change at the southern coast of Korea based on organic carbon isotope $\left(\delta^{13} \mathrm{C}\right)$ and $\mathrm{C} / \mathrm{S}$ ratios. Quatern. Int. 2015, 384, 160-168. [CrossRef]

5. Song, B.; Yi, S.; Yu, S.Y.; Nahm, W.H.; Lee, J.Y.; Lim, J.; Kim, J.C.; Yang, Z.Y.; Han, M.; Jo, K.N.; et al. Holocene relative sea-level changes inferred from multiple proxies on the west coast of South Korea. Palaeogeogr. Palaeocl. 2018, 496, 268-281. [CrossRef]

6. Tanigawa, K.; Hyodo, M.; Sato, H. Holocene relative sea-level change and rate of sea-level rise from coastal deposits in the Toyooka Basin, western Japan. Holocene 2013, 23, 1039-1051. [CrossRef]

7. Xiong, H.; Zong, Y.; Li, T.; Long, T.; Huang, G.; Fu, S. Coastal GIA processes revealed by the early to middle Holocene sea-level history of east China. Quat. Sci. Rev. 2020, 233, 106249. [CrossRef]

8. Nakanishi, T.; Hong, W.; Sung, K.S.; Lim, J. Radiocarbon reservoir effect from shell and plant pairs in Holocene sediments around the Yeongsan River in Korea. Nucl. Instrum. Meth. B 2013, 294, 444-451. [CrossRef]

9. Lim, J.; Lee, J.Y.; Hong, S.S.; Park, S.; Lee, E.; Yi, S. Holocene coastal environmental change and ENSO-driven hydroclimatic variability in East Asia. Quat. Sci. Rev. 2019, 220, 75-86. [CrossRef]

10. Lim, J.; Lee, J.Y.; Kim, J.C.; Hong, S.S.; Yang, D.Y. Relationship between environmental change on Geoje Island, southern coast of Korea, and regional monsoon and temperature changes during the late Holocene. Quatern. Int. 2014, 344, 11-16. [CrossRef]

11. Lee, E.; Yi, S.; Lim, J.; Kim, Y.; Jo, K.N.; Kim, G.Y. Multi-proxy records of Holocene hydroclimatic and environmental changes on the southern coast of South Korea. Palaeogeogr. Palaeoclimatol. Palaeocl. 2020, 545, 109642. [CrossRef]

12. Berner, R.A.; Raiswell, R. C/S method for distinguishing freshwater from marine sedimentary rocks. Geology 1984, 12, 365-368. [CrossRef]

13. Woolfe, K.J.; Dale, P.J.; Brunskill, G.J. Sedimentary C/S relationships in a large tropical estuary: Evidence for refractory carbon inputs from mangroves. Geo Mar. Lett. 1995, 15, 140-144. [CrossRef]

14. Ishihara, T.; Sugai, T.; Hachinohe, S. Fluvial response to sea-level changes since the latest Pleistocene in the near-coastal lowland, central Kanto Plain, Japan. Geomorphology 2012, 147, 49-60. [CrossRef]

15. Koma, T.; Suzuki, Y. Total sulfur content of Late Quaternary sediments in Shibakawa lowland, Saitama Prefecture, central Japan, and its relation to the sedimentary environment. Chem. Geol. 1988, 68, 221-228. [CrossRef]

16. Mackie, E.A.V.; Leng, M.J.; Lloyd, J.M.; Arrowsmith, C. Bulk organic $\delta^{13} \mathrm{C}$ and $\mathrm{C} / \mathrm{N}$ ratios as palaeosalinity indicators within a Scottish isolation basin. J. Quat. Sci. 2005, 20, 303-312. [CrossRef]

17. Hori, K.; Saito, Y.; Zhao, Q.H.; Cheng, X.R.; Wang, P.X.; Sato, Y.; Li, C.X. Sedimentary facies of the tide-dominated paleoChangiiang (Yangtze) estuary during the last transgression. Mar. Geol. 2001, 177, 331-351. [CrossRef]

18. Xiong, H.X.; Zong, Y.Q.; Qian, P.; Huang, G.Q.; Fu, S.Q. Holocene sea-level history of the northern coast of South China Sea. Quat. Sci. Rev. 2018, 194, 12-26. [CrossRef]

19. Kato, M.; Fukusawa, H.; Yasuda, Y. Varved lacustrine sediments of Lake Tougou-ike, Western Japan, with reference to Holocene sea-level changes in Japan. Quatern. Int. 2003, 105, 33-37. [CrossRef]

20. Lim, J.; Lee, J.Y.; Nahm, W.H.; Yi, S. Long-term vegetation change and controlling factors in Donghae area, Korea, over the past 40,000 years. Palaeogeogr. Palaeocl. 2011, 309, 291-297. [CrossRef]

21. Lim, J.; Matsumoto, E. Fine aeolian quartz records in Cheju Island, Korea, during the last 6500 years and pathway change of the westerlies over east Asia. J. Geophys. Res. Atmos. 2008, 113. [CrossRef] 
22. Lim, J.; Matsumoto, E.; Kitagawa, H. Eolian quartz flux variations in Cheju Island, Korea, during the last 6500 yr and a possible Sun-monsoon linkage. Quat. Res. 2005, 64, 12-20. [CrossRef]

23. Lim, J.; Nahm, W.-H.; Kim, J.-K.; Yang, D.-Y. Regional climate-driven C3 and C4 plant variation in the Cheollipo area, Korea, during the late Pleistocene. Palaeogeogr. Palaeoclimatol. Palaeoecol. 2010, 298, 370-377. [CrossRef]

24. Lim, J.; Yang, D.Y.; Lee, J.Y.; Hong, S.S.; Um, I.K. Middle Holocene environmental change in central Korea and its linkage to summer and winter monsoon changes. Quat. Res. 2015, 84, 37-45. [CrossRef]

25. Lim, J.; Yi, S.; Nahm, W.H.; Kim, J.Y. Holocene millennial-scale vegetation changes in the Yugu floodplain, Kongju area, central South Korea. Quatern. Int. 2012, 254, 92-98. [CrossRef]

26. Park, J.; Park, J.; Yi, S.; Cheul Kim, J.; Lee, E.; Choi, J. Abrupt Holocene climate shifts in coastal East Asia, including the 8.2 ka, $4.2 \mathrm{ka}$, and $2.8 \mathrm{ka}$ BP events, and societal responses on the Korean peninsula. Sci. Rep. 2019, 9, 10806. [CrossRef]

27. Park, J.; Shin, Y.H.; Byrne, R. Late-Holocene vegetation and climate change in Jeju Island, Korea and its implications for ENSO influences. Quat. Sci. Rev. 2016, 153, 40-50. [CrossRef]

28. Park, S.; Lim, J.; Lim, H.S. Past climate changes over South Korea during MIS3 and MIS1 and their links to regional and global climate changes. Quatern. Int. 2019, 519, 74-81. [CrossRef]

29. Bae, S.W.; Lee, K.E.; Chang, T.S. Two long and pronounced cold periods 3,000-5,000 and 6,600-8,400 years B.P. in East Asia and the southward migration of the westerly jet. Palaeogeogr. Palaeoclimatol. Palaeoecol. 2020, 537, 109402. [CrossRef]

30. Dykoski, C.A.; Edwards, R.L.; Cheng, H.; Yuan, D.X.; Cai, Y.J.; Zhang, M.L.; Lin, Y.S.; Qing, J.M.; An, Z.S.; Revenaugh, J. A high-resolution, absolute-dated Holocene and deglacial Asian monsoon record from Dongge Cave, China. Earth Planet. Sci. Lett. 2005, 233, 71-86. [CrossRef]

31. Stott, L.; Cannariato, K.; Thunell, R.; Haug, G.H.; Koutavas, A.; Lund, S. Decline of surface temperature and salinity in the western tropical Pacific Ocean in the Holocene epoch. Nature 2004, 431, 56-59. [CrossRef] [PubMed] 